\title{
Status of Trace Minerals And Colostral Immunoglobulin's In Periparturient Goats And Its Significance On Morbidity And Mortality of Goat Kids In Semi-Arid Zone of Northern Plains of India
}

\section{Arvind Kumar Tripathi}

U.P. Pt. Deen Dayal Upadhyay Pashu Chikitsa Vigyan Vishwavidyalay evam Go Anusandhan Sansthan (DUVASU)

\section{Ashok Kumar}

ICAR-Central Institute for Research on Goats

Padma Nibash Panigrahi ( $\square$ pnpvetmed@gmail.com)

U.P. Pt. Deen Dayal Upadhyay Pashu Chikitsa Vigyan Vishwavidyalay evam Go Anusandhan Sansthan (DUVASU)

Ashish Srivastava

U.P. Pt. Deen Dayal Upadhyay Pashu Chikitsa Vigyan Vishwavidyalay evam Go Anusandhan Sansthan (DUVASU)

\section{Research Article}

Keywords: Trace minerals status, Periparturient Goat, Breeds, Colostral Immunoglobulins, Goat Kids, Morbidity, Mortality

Posted Date: December 21st, 2021

DOI: https://doi.org/10.21203/rs.3.rs-1130002/v1

License: (1) This work is licensed under a Creative Commons Attribution 4.0 International License. Read Full License 


\section{Abstract}

The present study was designed to evaluate the variations of trace minerals status in blood at different stages of periparturient periods and colostrum and milk, colostrum immunoglobulin's and morbidity and mortality were also evaluated in various recognized breeds of goats maintained at organized farms of CIRG in comparison to the non-descript goats maintained at farmers field flock. The results reveal that blood, colostrum and milk levels of zinc ( $\mathrm{Zn})$, copper (Cu), iron ( $\mathrm{Fe}$ ) manganese ( $\mathrm{Mn})$ and cobalt (Co) were found to be significantly lower at different stages of periparturient period in the Non-descript breed of goats of maintained at farmers field flock. The colostrum immunoglobulin's (IgG, IgM and IgA) were also found to be lowest in the non-descript breed of goats than recognized breeds of goats. The morbidity and mortality were found to be highest in goat kids born of non-descript breed of goats during pre weaning period in comparison to the recognized breeds. It can be concluded that the lower level of trace minerals during periparturient period in non-descript goats of farmers field flocks might results in lower level of colostral immunoglobulin's hence poor transfer of passive immunity in goat kids. Therefore, high morbidity and mortality of goat kids during pre weaning period than recognized breed of goats of the organized farms.

\section{Introduction:}

The trace mineral status of an animal is important during times of stress, especially for transition period because of stress due to fetal growth, colostrums production, as well as other hormonal, physiological, dietary and environmental changes they face (Leeson 2005). Trace minerals such as copper, zinc and selenium deficiencies, impaired colostral transfer of immunoglobulin is the major reason of this decreased resistance of calves, mainly resulting in perinatal mortality and diarrhoea and can also impair acquired immunity in older calves (Enjalbert et al. 2006). Managing the risks due to trace elements deficiencies in neonates, first needs an assessment of the trace mineral status of the herds, and because the trace element status of the dams strongly influences the mineral status of the newborn and colostral transfer of passive immunity, this assessment must be performed based on blood analysis (Kincaid 1999). However, there is scarcity of information on blood, colostrum and milk levels of trace minerals and immune status of goats during periparturient periods. Therefore, to fulfill this research gap, present study was undertaken to evaluate the status of trace minerals and colostrum immunoglobulin's in periparturient goats in semi-arid zone of northern plains of India

\section{Materials And Methods:}

The study was conducted at Indian Council of Agricultural Research - Central Institute for Research on Goats (ICAR - CIRG), Mathura. The institute is located at an altitude of 163.4 meters above mean sea level at latitude of $27.10^{\circ} \mathrm{N}$ and a longitude of $77.9^{\circ} \mathrm{E}$. The area has semi-arid climate and receives rain mostly in monsoon season of July to September. The entire farm level study was conducted on pregnant goats in the July-December season of breeding in the year 2017-18.

Fourty (40) healthy pregnant goats of various breed were selected from organised farms of ICAR-Central Institute for Research on Goats, Makhdoom, Farah, Mathura and farmers flocks of local farmers in and around Mathura $(n=10)$. Three recognized breed of goat's viz. Jamunapari, Barbari, Jakharana maintained at organized farms in different units of CIRG in semi-intensive system of rearing with continuous provisions of fodder and concentrates in the diet apart from grazing. However, non-descript goats $(n=10)$ from local villagers (farmers field flock) maintained on extensive system of rearing without any extra provisions of fodder and concentrates in the diet. Recognized breed of goat's were properly vaccinated for PPR, ET, FMD and Goat pox with regular deworming at the farms while no such practices were adopted in the farmers field flocks by local villagers.

Goats of various breeds with similar mean parity were selected after completion of about 2 months of pregnancy based on breeding record. Selected goats were kept with flock on common feed source and grazing area with clean drinking water was provided ad libitum twice a day as per the rearing practice followed at livestock farm.

\begin{tabular}{|llll|}
\hline Rearing system & Breeds / Groups ( $\mathbf{n = 1 0 )}$ & Mean of parity & Mean Litter Size \\
\hline \multirow{2}{*}{ Organized farm } & Jamunapari & 2.21 & 1.6 \\
\cline { 2 - 4 } & Barbari & 2.21 & 1.3 \\
\cline { 2 - 4 } & Jakharana & 2.21 & 1.7 \\
\hline Farmers field flock & Non-descript & 2.21 & 1.5 \\
\hline
\end{tabular}

Blood samples were collected from six selected pregnant goats of various breeds having similar mean parity by jugular venipuncture using heparinised sterile blood collection tubes $\left(V^{2}\right.$ acuette ${ }^{\circledR}$ - Greiner Bio-One $\mathrm{GmbH}$, Austria) and $02 \mathrm{ml}$ blood was collected at mid gestation, four 
weeks prior to parturition, on the day of parturition and four weeks after parturition and processed and stored in $-20^{\circ} \mathrm{C}$ for estimation of trace minerals ( $\mathrm{Zn}, \mathrm{Cu}, \mathrm{Fe}, \mathrm{Mn}$ and $\mathrm{Co})$.

Colostrum samples from the six selected pregnant goats of various breeds having similar mean parity were collected by hand milking as soon as possible after kidding, 05 milliliters of first colostrum (prior to suckling by the kid) was collected in sterile polypropylene centrifuge tubes $\left(\right.$ Tarsons ${ }^{\circledR}$ ). Milk samples from the six selected pregnant goats of various breeds having similar mean parity were collected by hand milking after four weeks of kidding, 05 milliliters of milk was collected in sterile polypropylene centrifuge tubes (Tarsons $\left.{ }^{\circledR}\right)$. Both colostrum and milk samples were processed and stored in $-20^{\circ} \mathrm{C}$ for estimation of trace minerals ( $\mathrm{Zn}, \mathrm{Cu}, \mathrm{Fe}, \mathrm{Mn}$ and $\left.\mathrm{Co}\right)$.

$1 \mathrm{ml}$ sample of blood, colostrum and milk from individual animals from various breeds of goats were digested in digestion flask containing $20 \mathrm{ml}$ of triple acid mixture at higher temperature on the hot plate till the contents are clear and perchloric acid $\left(\mathrm{HClO}_{4}\right)$ fumes decreased to come out. The final volume was made to $25 \mathrm{ml}$ and filtered through Whatman filter paper 42 to remove silica and other insoluble residues from digested samples. Estimation of trace minerals ( $\mathrm{Zn}, \mathrm{Cu}, \mathrm{Fe}, \mathrm{Mn}$ and $\mathrm{Co}$ ) in blood, colostrum and milk samples from various breeds of goats were analyzed by Atomic Absorption Spectrophotometer (Model No. AAS 400; Perkin Elmer, USA). Zn, Cu, Fe and Mn were estimated by using flame mode of AAS while Co was estimated with the help of graphite mode of AAS. A series of working standards were run in AAS for the preparation of the standard curve (Zn: 0.5, 0.75, 1.0 ppm, Cu: 0.5, 1.0, 1.5 ppm, Fe: 1.0, 2.0, 3.0 ppm, Mn: 0.5, 0.75, 1.0 ppm and Co : $20 \mathrm{ppb}$ ). Finally the samples were run and the readings were noted. Concentrations of minerals were estimated by multiplying AAS value with dilution factor.

20 milliliters of first drawn colostrum was collected from six selected goats of each breed in sterile 50 ml polypropylene centrifuge tubes $\left(\right.$ Tarsons $^{\circledR}$ ) and stored at $-20^{\circ} \mathrm{C}$ for further analysis. After collection of colostrum of all the goats of various breeds, it was made fat free colostrum for measurement of $\lg$, $\lg M$ and $\lg A$.

$10 \mathrm{ml}$ colostrum of each animals of various breeds of goats were centrifuged in $15 \mathrm{ml}$ polypropylene centrifuge tubes $\left(\right.$ Tarsons $\left.^{\circledR}\right)$ at $6000 \mathrm{~g}$ for 30 minutes at $25^{\circ} \mathrm{C}$ resulting in separation of fat at top of the tube. $05 \mathrm{ml}$ fat free colostrum was taken from below the fat layer using 05 $\mathrm{ml}$ sterile syringe and 16 gauge sterile hypodermic needle. $05 \mathrm{ml}$ of fat free colostrum was diluted 1:1 with sterile PBS and again centrifuged at $3000 \mathrm{~g} \mathrm{X} 30$ minutes at $4^{\circ} \mathrm{C}$ resulting in separation of residual fat. $05 \mathrm{ml}$ of this fat free and diluted colostrum was again collected from below the fat layer using $05 \mathrm{ml}$ sterile syringe and 16 gauge sterile hypodermic needle. The obtained fat free colostrum was then divided into 03 aliquots of $01 \mathrm{ml}$ each, processed and stored in cryovials at temperature $<-20^{\circ} \mathrm{C}$ for further analysis.

IgG, IgM and IgA were estimated in fat free colostrum using goat specific quantitative ELISA kits (Bioassay Technology Laboratory, Shanghai, China). CurveExpert basic version 1.4 software was used to draw standard curve for ELISA.

Health status of all kids born live from all selected goats of various breeds under study were observed on daily basis by the attending veterinarian and all disease occurrence/morbidity and mortality if any were recorded. Diseased kids were isolated from the group and treated separately. Data were recorded from various breeds under study on monthly basis and analyzed to assess the percent disease incidence/morbidity and mortality if any from birth to up to three month (weaning). Every death is recorded and post-mortem (PM) examination is conducted by a veterinarian as standard practice. Mortality due to trauma or predation was not considered in the study.

\section{Results And Discussion:}

There is very scanty information about the trace mineral status during periparturient period in goats, therefore the present study was undertaken with the objective to determine the variations in the blood levels of zinc, copper, iron, manganese and cobalt at various stages of periparturient period in various breeds of goats

Blood levels of zinc ( $\mathrm{Zn})$, copper ( $\mathrm{Cu}$ ), iron (Fe) manganese (Mn) and cobalt (Co) were found to be similar in the recognized breeds (Jamunapari, Barbari and Jakharana) of goats at different stages of periparturient period, but the values were found significantly lower at different stages of periparturient period in the non-descript breed of goats in comparison to the recognized breeds under study (Table 1-5). The recognized breeds of goats under study were maintained on the semi-intensive system of rearing at organized farms of the institute and they have continuous supplementation of fodder and concentrates in the diet apart from grazing. However, non-descript breed of selected goats only maintained on free-range grazing systems at farmers field flock by local villagers and therefore they are absolutely dependent on pasture only for trace minerals as they have very limited or no opportunities of trace mineral supplements via fodder and concentrates, hence it may be due to poor nutritional status of non-descript goats of farmers field flocks, because they are only maintained on grazing which may exhibit trace mineral deficiency as soils and forages contain limited concentrations (Hill and Shannon 2019). The status of trace minerals in blood is directly depending on diet or nutritional status of the animals (Condron et al. 2000). These findings 
simulates with earlier report about the status of trace minerals in cattle of Mathura and adjoining areas, deficit of copper in heifers (Gupta et al. 2015) and copper, zinc and cobalt in cattle had been reported (Sharma et al. 2006).

Table 1

Mean \pm SE values of Zinc (mg/L) in blood of various breeds of goats during periparturient period

\begin{tabular}{|c|c|c|c|c|}
\hline Groups/Breeds & Mid gestation & 4 week prepartum & Parturition & 4 week post partum \\
\hline \multirow[t]{2}{*}{ Jamunapari } & 1.836 & 1.866 & $2.535^{a}$ & 1.857 \\
\hline & \pm 0.044 & \pm 0.033 & \pm 0.030 & \pm 0.028 \\
\hline \multirow[t]{2}{*}{ Barbari } & 1.827 & 1.846 & $2.537^{b}$ & 1.821 \\
\hline & \pm 0.030 & \pm 0.031 & \pm 0.030 & \pm 0.027 \\
\hline \multirow[t]{2}{*}{ Jakharana } & 1.851 & 1.864 & $2.568^{c}$ & 1.824 \\
\hline & \pm 0.025 & \pm 0.017 & \pm 0.023 & \pm 0.017 \\
\hline \multirow[t]{2}{*}{ Non-descript } & $1.616^{\mathrm{A}}$ & $1.645^{\mathrm{B}}$ & $2.226^{\mathrm{Cd}}$ & $1.621^{\mathrm{D}}$ \\
\hline & \pm 0.039 & \pm 0.034 & \pm 0.024 & \pm 0.034 \\
\hline
\end{tabular}

Table 2

Mean \pm SE values of Copper $(\mathrm{mg} / \mathrm{L})$ in blood samples of various breeds of goats during periparturient period

\begin{tabular}{|c|c|c|c|c|}
\hline Groups / Breeds & Mid gestation & 4 week prepartum & Parturition & 4 week post partum \\
\hline \multirow[t]{2}{*}{ Jamunapari } & $4.831^{a}$ & $4.744^{a}$ & $3.388^{b}$ & $2.339^{c}$ \\
\hline & \pm 0.055 & \pm 0.048 & \pm 0.063 & \pm 0.059 \\
\hline \multirow[t]{2}{*}{ Barbari } & $4.824^{d}$ & $4.687^{d}$ & $3.368^{e}$ & $2.348^{f}$ \\
\hline & \pm 0.060 & \pm 0.042 & \pm 0.064 & \pm 0.044 \\
\hline \multirow[t]{2}{*}{ Jakharana } & $4.812^{\mathrm{g}}$ & $4.745^{\mathrm{g}}$ & $3.399^{h}$ & $2.343^{\mathrm{i}}$ \\
\hline & \pm 0.056 & \pm 0.043 & \pm 0.060 & \pm 0.038 \\
\hline \multirow[t]{2}{*}{ Non-descript } & $3.859^{\mathrm{Aj}}$ & $3.779^{\mathrm{Bj}}$ & $2.185^{\mathrm{Ck}}$ & $1.77^{\mathrm{DI}}$ \\
\hline & \pm 0.079 & \pm 0.079 & \pm 0.141 & \pm 0.096 \\
\hline \multicolumn{5}{|c|}{ Mean with different superscript $(A-D)$ in columns are differing significantly in between the groups, otherwise non-significant $(p<0.05)$} \\
\hline
\end{tabular}


Table 3

Mean \pm SE values of Iron (mg/L) in blood of various breeds of goats during periparturient period

\begin{tabular}{|c|c|c|c|c|}
\hline Groups/Breeds & Mid gestation & 4 week prepartum & Parturition & 4 week post partum \\
\hline \multirow[t]{2}{*}{ Jamunapari } & 2.41 & 2.83 & 1.69 & 1.95 \\
\hline & $\pm 0.06^{a}$ & $\pm 0.07^{b}$ & $\pm 0.06^{c}$ & $\pm 0.04^{d}$ \\
\hline \multirow[t]{2}{*}{ Barbari } & 2.42 & 2.80 & 1.58 & 1.89 \\
\hline & $\pm 0.08^{a}$ & $\pm 0.03^{b}$ & $\pm 0.06^{c}$ & $\pm 0.05^{\mathrm{d}}$ \\
\hline \multirow[t]{2}{*}{ Jakharana } & 2.61 & 2.94 & 1.75 & 2.03 \\
\hline & $\pm 0.07^{a}$ & $\pm 0.06^{b}$ & $\pm 0.04^{c}$ & $\pm 0.05^{d}$ \\
\hline \multirow[t]{2}{*}{ Non-descript } & 2.11 & 2.41 & 1.36 & 1.69 \\
\hline & $\pm 0.03^{\mathrm{Aa}}$ & $\pm 0.04^{\mathrm{Bb}}$ & $\pm 0.04^{\mathrm{Cc}}$ & $\pm 0.03^{\mathrm{Dd}}$ \\
\hline \multicolumn{5}{|c|}{ Mean with different superscript $(A-D)$ in columns are differing significantly in between the groups, otherwise non-significant $(p<0.05)$} \\
\hline
\end{tabular}

Table 4

Mean \pm SE values of Manganese $(\mathrm{mg} / \mathrm{L})$ in blood of various breeds of goats during periparturient period

\begin{tabular}{|c|c|c|c|c|}
\hline Groups/Breeds & Mid gestation & 4 week prepartum & Parturition & 4 week post partum \\
\hline \multirow[t]{2}{*}{ Jamunapari } & 2.59 & 3.26 & 1.54 & 1.97 \\
\hline & $\pm 0.04^{a}$ & $\pm 0.07^{b}$ & $\pm 0.05^{c}$ & $\pm 0.06^{d}$ \\
\hline \multirow[t]{2}{*}{ Barbari } & 2.57 & 3.41 & 1.57 & 1.99 \\
\hline & $\pm 0.04^{a}$ & $\pm 0.08^{b}$ & $\pm 0.05^{c}$ & $\pm 0.05^{d}$ \\
\hline \multirow[t]{2}{*}{ Jakhrana } & 2.60 & 3.28 & 1.56 & 1.98 \\
\hline & $\pm 0.04^{a}$ & $\pm 0.07^{b}$ & $\pm 0.05^{c}$ & $\pm 0.05^{d}$ \\
\hline \multirow[t]{2}{*}{ Non-descript } & 1.76 & 2.74 & 1.24 & 1.56 \\
\hline & $\pm 0.05^{\mathrm{Aa}}$ & $\pm 0.07^{\mathrm{Bb}}$ & $\pm 0.02^{\mathrm{Cc}}$ & $\pm 0.03^{\mathrm{Dd}}$ \\
\hline \multicolumn{5}{|c|}{ Mean with different superscript $(A-D)$ in columns are differing significantly in between the groups, otherwise non-significant $(p<0.05)$} \\
\hline
\end{tabular}


Table 5

Mean \pm SE values of Cobalt $(\mu \mathrm{g} / \mathrm{L})$ in blood of various breeds of goats during periparturient period

\begin{tabular}{|c|c|c|c|c|}
\hline Groups/Breeds & Mid gestation & 4 week prepartum & Parturition & 4 week post partum \\
\hline \multirow[t]{2}{*}{ Jamunapari } & 149.31 & 181.30 & 79.78 & 135.87 \\
\hline & $\pm 4.12^{a}$ & $\pm 2.20^{\mathrm{b}}$ & $\pm 1.53^{c}$ & $\pm 1.60^{d}$ \\
\hline \multirow[t]{2}{*}{ Barbari } & 149.66 & 181.48 & 79.72 & 136.52 \\
\hline & $\pm 3.65^{a}$ & $\pm 1.51^{b}$ & $\pm 1.28^{c}$ & $\pm 1.80^{d}$ \\
\hline \multirow[t]{2}{*}{ Jakharana } & 150.19 & 181.17 & 79.18 & 137.16 \\
\hline & $\pm 3.88^{a}$ & $\pm 2.04^{\mathrm{b}}$ & $\pm 1.41^{\mathrm{c}}$ & $\pm 1.49^{d}$ \\
\hline \multirow[t]{2}{*}{ Non-descript } & 105.21 & 126.16 & 65.40 & 92.19 \\
\hline & $\pm 2.21^{\mathrm{Aa}}$ & $\pm 3.63^{\mathrm{Bb}}$ & $\pm 0.89^{\mathrm{Cc}}$ & $\pm 1.32^{\mathrm{Dd}}$ \\
\hline \multicolumn{5}{|c|}{ Mean with different superscript $(A-D)$ in columns are differing significantly in between the groups, otherwise non-significant $(p<0.05)$} \\
\hline
\end{tabular}

It was also observed in the all the breed of goats under study that the blood levels of Zn, Fe, Mn and Co showed increasing trends from mid gestation to parturition and thereafter it showed a decreasing trend from parturition to four weeks post-partum, these finding observed in present investigation are in partial agreement of the finding in which it was reported that decreasing tendency of iron towards parturition, increasing trend for zinc and copper at the day of parturition and increase thereafter in buffaloes (Akhtar et al. 2009). The variations of trace minerals during gestation was reported that concentrations of essential trace micro minerals (Cu, Zn, Fe) decreased during pregnancy or late period of gestation in single and twin pregnant ewes (Abdollahi et al. 2013). Blood level of Cu showed a decreasing trend throughout the periparturient period in present investigation, which is in the accordance of the findings earlier reported by various workers that copper in serum was higher at estrus and depressed on the day of calving (Small 1997; Xin et al. 1993). Significant increase in blood Mn concentrations with increasing gestational age had been reported (Mora et al. 2014). Variation in the level of cobalt during periparturient period could not be explained due to paucity of literature. These variations in trace minerals during periparturient period in present investigation may be in response to colostrogenesis (Meglia et al. 2001).

Colostrum and milk levels were also assessed in the selected goats and it was observed that zinc ( $\mathrm{Zn}$ ), copper (Cu), iron (Fe) manganese $(\mathrm{Mn})$ and cobalt (Co) levels were found to be similar in the recognized breeds (Jamunapari, Barbari and Jakharana) of goats of organized farms (Table 6-10) but values in non-descript breed of goat of farmers field flock were found significantly lower in colostrum and milk samples (Condron et al. 2000). These findings might be due to poor nutritional status of non-descript goats as they had low blood level of these trace minerals, therefore the trace minerals levels of colostrum and milk levels were found to be low than the recognized breed under study as they are maintained on the good dietary nutrition (Leeson 2005). 
Table 6

Mean \pm SE values of Zinc $(\mathrm{mg} / \mathrm{L})$ in colostrum and milk of various breeds of goats

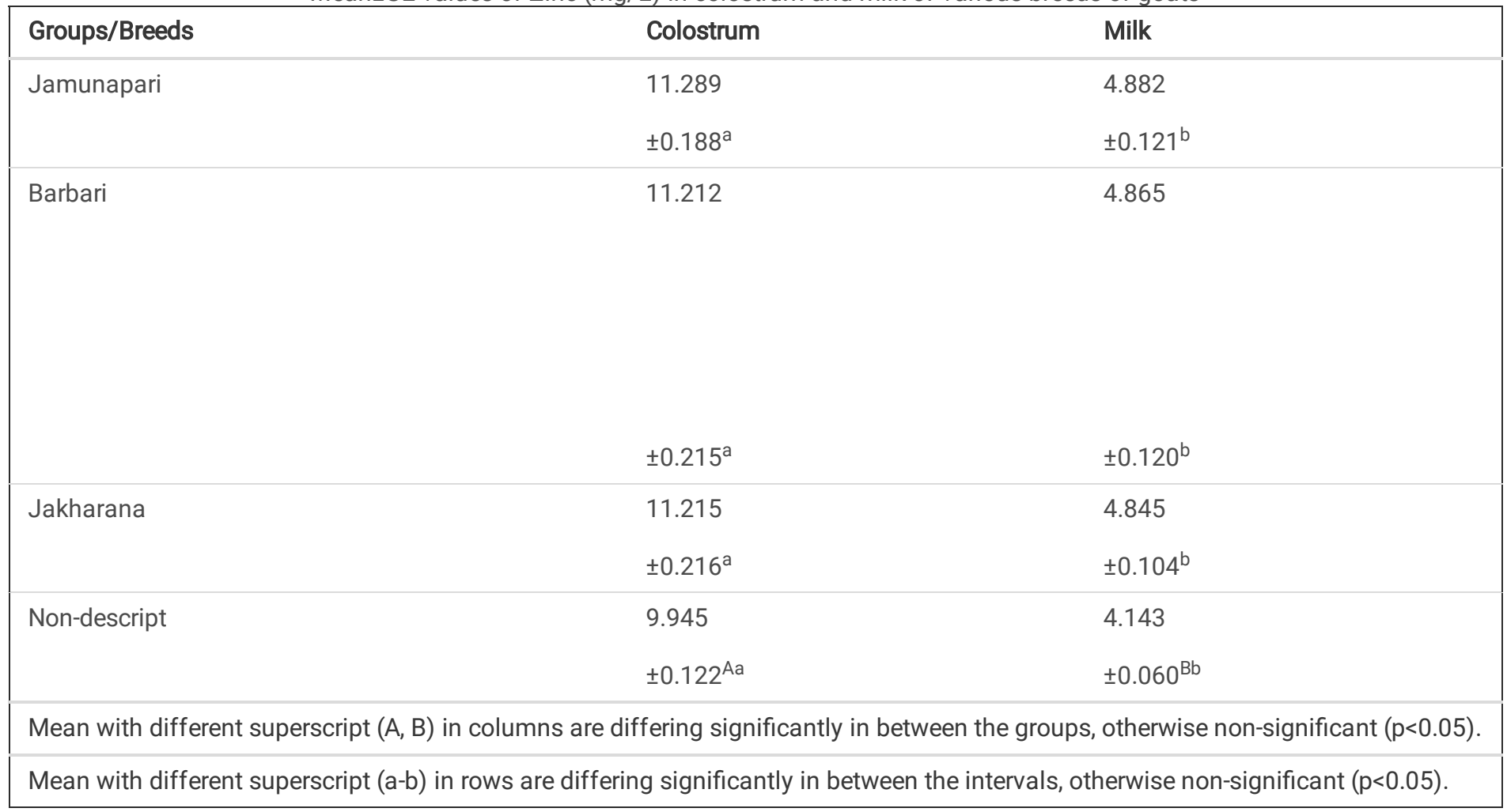

Table 7

Mean \pm SE values of Copper (mg/L) in colostrum and milk of various breeds of goats

\begin{tabular}{|c|c|c|}
\hline Groups/Breeds & Colostrum & Milk \\
\hline \multirow[t]{2}{*}{ Jamunapari } & 0.318 & 0.106 \\
\hline & $\pm 0.012^{a}$ & $\pm 0.009^{b}$ \\
\hline \multirow[t]{2}{*}{ Barbari } & 0.316 & 0.103 \\
\hline & $\pm 0.016^{a}$ & $\pm 0.008^{b}$ \\
\hline \multirow[t]{2}{*}{ Jakharana } & 0.307 & 0.103 \\
\hline & $\pm 0.008^{a}$ & $\pm 0.006^{b}$ \\
\hline \multirow[t]{2}{*}{ Non-descript } & 0.252 & 0.071 \\
\hline & $\pm 0.013^{\mathrm{Aa}}$ & $\pm 0.005^{\mathrm{Bb}}$ \\
\hline \multicolumn{3}{|c|}{ Mean with different superscript (A, B) in columns are differing significantly in between the groups, otherwise non-significant $(p<0.05)$. } \\
\hline
\end{tabular}


Table 8

Mean \pm SE values of Iron (mg/L) in colostrum and milk of various breeds of goats

\begin{tabular}{|c|c|c|}
\hline Groups/Breeds & Colostrum & Milk \\
\hline \multirow[t]{2}{*}{ Jamunapari } & 1.76 & 0.35 \\
\hline & $\pm 0.05^{\mathrm{a}}$ & $\pm 0.01^{b}$ \\
\hline \multirow[t]{2}{*}{ Barbari } & 1.72 & 0.34 \\
\hline & $\pm 0.04^{a}$ & $\pm 0.01^{b}$ \\
\hline \multirow[t]{2}{*}{ Jakharana } & 1.71 & 0.33 \\
\hline & $\pm 0.03^{a}$ & $\pm 0.01^{b}$ \\
\hline \multirow[t]{2}{*}{ Non-descript } & 1.46 & 0.29 \\
\hline & $\pm 0.04^{\mathrm{Aa}}$ & $\pm 0.01^{\mathrm{Bb}}$ \\
\hline \multicolumn{3}{|c|}{ Mean with different superscript $(A, B)$ in columns are differing significantly in between the groups, otherwise non-significant ( $<<0.05)$} \\
\hline
\end{tabular}

Table 9

Mean $\pm S E$ values of Manganese $(\mathrm{mg} / \mathrm{L})$ in colostrum and milk of various breeds of goats

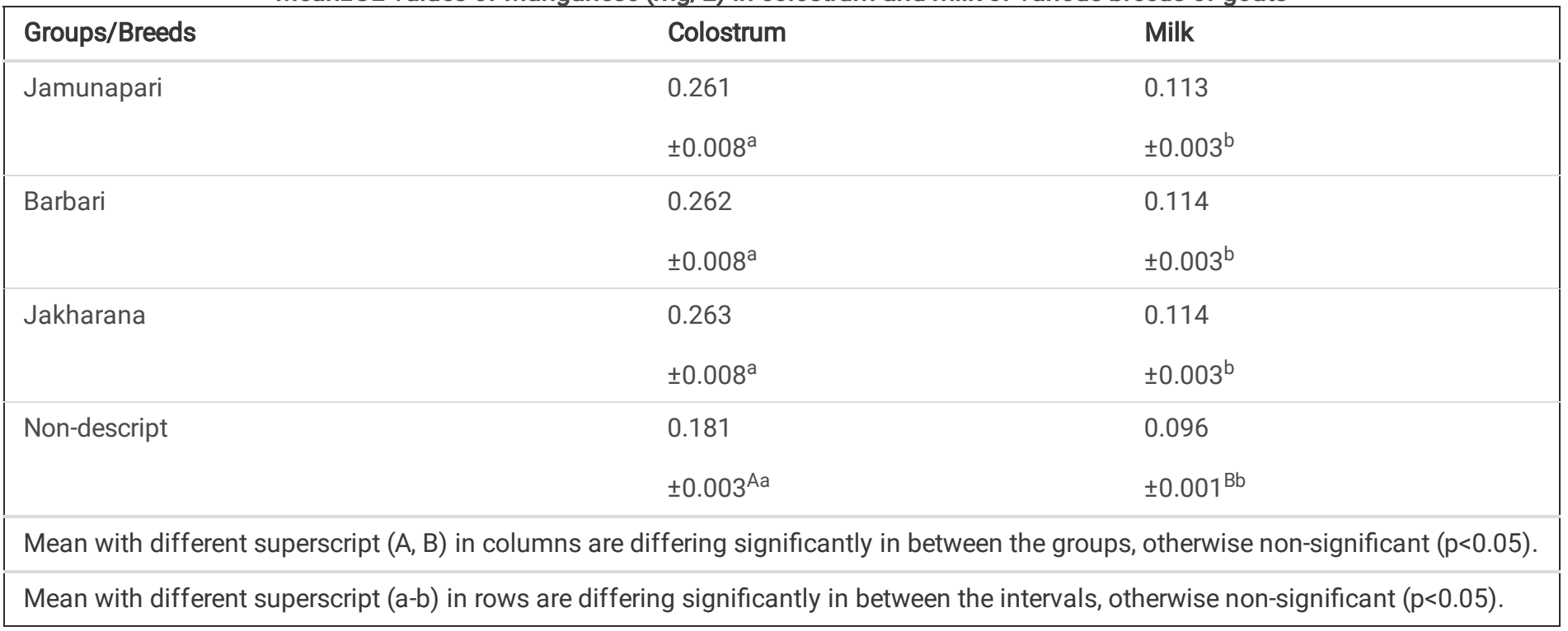


Table 10

Mean \pm SE values of Cobalt $(\mu \mathrm{g} / \mathrm{L})$ in colostrum and milk of various breeds of goats

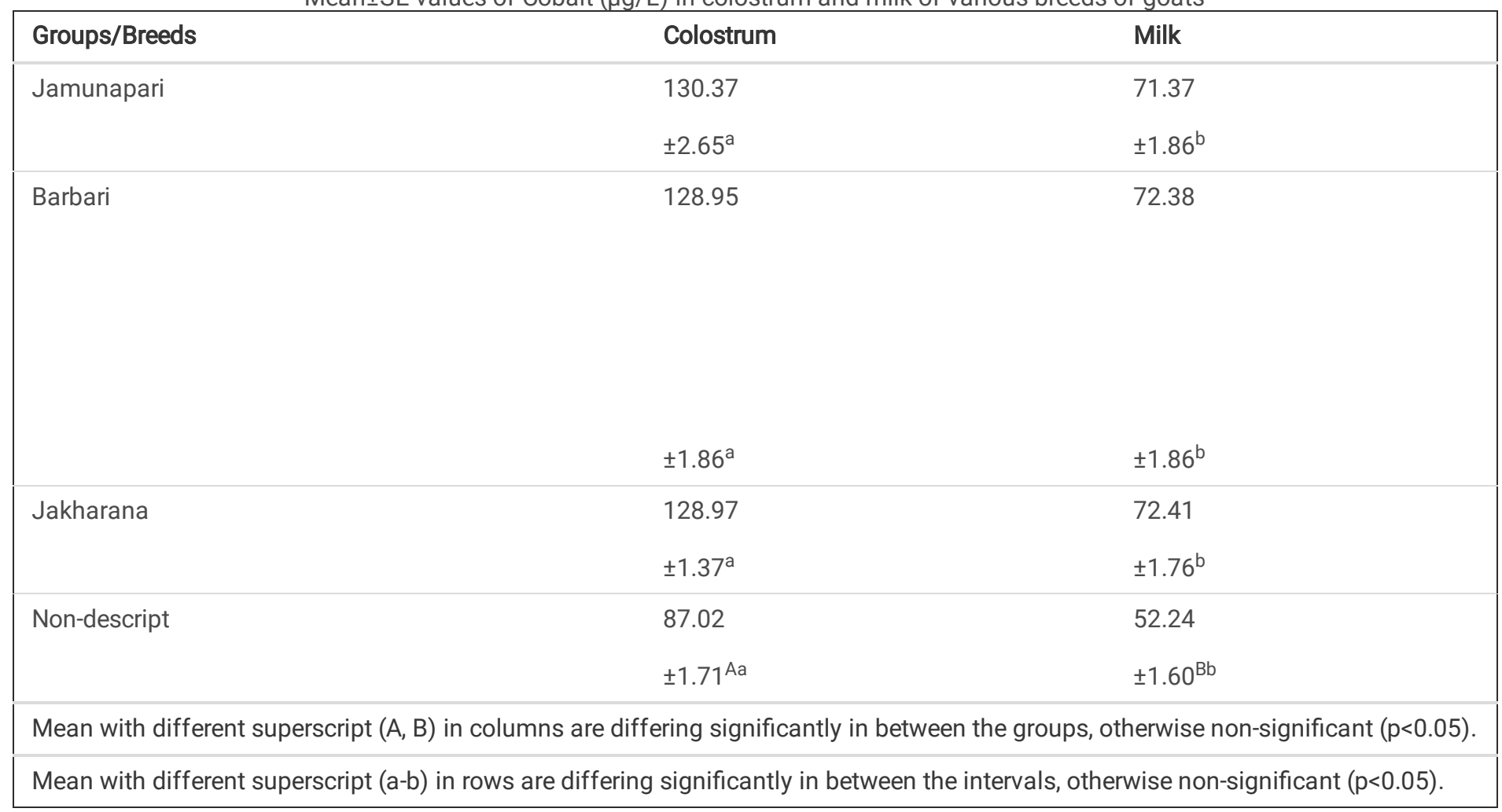

It was also observed in the all the breed of goats under study that the colostrum levels of zinc, copper, iron, manganese and cobalt were found to be significantly higher in comparison to the milk samples after four weeks of kidding, showing a decreasing trend from colostrum to milk. Relatively very little work has been done on assessment of trace minerals concentrations in colostrum and milk during the early post-partum period. However, it was reported that the average concentrations of copper, iron, zinc and manganese in colostrum were many fold higher than values for normal milk (Kehoe et al. 2007). It was also observed that no particular trends for the concentrations of copper and iron in colostrum over the first $108 \mathrm{~h}$ post-partum; the concentration of zinc was highest in the first milking, but decreased sharply thereafter, while no manganese was detected in colostrum (Jeong et al. 2009). While a general decrease in the levels of copper, iron and zinc level from colostrum to milk had been reported (Abd El Fattah et al. 2012, Quigley and Drewry 1998).

The colostrum immunoglobulin's (IgG, IgM and IgA) were assessed in the selected goats, revealed a significantly lower values of all the three colostral immunoglobulin's (IgG, IgM, IgA) in the non-descript breed of goats of the farmers field flocks in comparison to the recognized breeds of goats, however; the values of colostral immunoglobulins $(\operatorname{lgG}, \operatorname{lgM}, \lg A)$ were found to be similar in the recognized breeds of Jamunapari, Barbari and Jakharana of the organized farms (Table 11). The reduction in the values colostral immunoglobulin's in non-descript goat might be due to fact that they are maintained on a low plane of nutrition than the recognized breed of goats under study. These findings are in agreement with the findings earlier reported that diet plays a significant role in enhancement of immune responses of small ruminants around parturition (Caroprese et al. 2015). Trace minerals deficiencies, may impair colostral transfer of immunoglobulin, which is the might be the reason of decreased immunoglobulin's in the colostrum of Non-descript goats (Enjalbert et al. 2006). 
Table 11

Mean \pm SE values of immunoglobulins in colostrum of various breeds of goat using quantitative ELISA kits

\begin{tabular}{|c|c|c|c|c|}
\hline Parameters & Jamunapari & Barbari & Jakharana & Non-descript \\
\hline \multirow[t]{2}{*}{$\lg G(\mathrm{mg} / \mathrm{ml})$} & 63.232 & 63.167 & 63.402 & 57.286 \\
\hline & $\pm 1.447^{a}$ & $\pm 1.427^{a}$ & $\pm 1.384^{a}$ & $\pm 0.896^{b}$ \\
\hline \multirow[t]{2}{*}{$\operatorname{lgM}(\mu \mathrm{g} / \mathrm{ml})$} & 1931 & 1924.8 & 1941.8 & 1699.2 \\
\hline & $\pm 25.704^{a}$ & $\pm 47.649^{\mathrm{a}}$ & $\pm 34.312^{\mathrm{a}}$ & $\pm 28.523^{b}$ \\
\hline \multirow[t]{2}{*}{$\operatorname{lgA}(\mu \mathrm{g} / \mathrm{ml})$} & 959.8 & 959.4 & 961 & 810 \\
\hline & $\pm 12.677^{a}$ & $\pm 19.846^{a}$ & $\pm 14.734^{\mathrm{a}}$ & $\pm 13.372^{b}$ \\
\hline
\end{tabular}

The highest morbidity and mortality was recorded in goat kids born of non-descript breed of goats in first month, second month and third month in comparison to the recognized breeds of goats' viz. Jamunapari, Barbari and Jakharana (Table 12). Failure of passive transfer of immunity (FPTI) due to poor quality of colostrum viz. reduced levels of colostrum immunoglobulin's and trace minerals status in present investigation might be the reason for increased morbidity and mortality in goat kids born from non-descript breed of goats. It is very well known fact that neonates of farmed ruminants are agammaglobulinemic at birth and have immature innate and adaptive immune system and to resist infections in early postnatal life, they solely depend on maternal immunoglobulins present in colostrum (Radostits et al. 2007). It is also reported that moderate trace mineral deficiencies are more likely to occur, especially during the transition period, affecting the health of both cows and calves (Linn et al. 2011). The high kid morbidity/mortality is the most significant syndrome affecting the goat rearing and the main losses occurred in the first three months of life. Therefore, efforts should be made to minimize neonatal morbidity/mortality of goat kids to overcome this problem and to make goat rearing more profitable.

Table 12

Percent disease incidence/morbidity and mortality in neonatal goat kids born live from selected goats of various breeds up to weaning

\begin{tabular}{|c|c|c|c|c|c|c|c|c|c|c|c|c|}
\hline \multirow[t]{2}{*}{$\begin{array}{l}\text { Breed of } \\
\text { goats }\end{array}$} & \multirow{2}{*}{$\begin{array}{l}\text { No } \\
\text { of } \\
\text { dam }\end{array}$} & \multirow{2}{*}{$\begin{array}{l}\text { No } \\
\text { of } \\
\text { kids } \\
\text { born } \\
\text { live }\end{array}$} & \multicolumn{4}{|c|}{$\begin{array}{l}\text { Percent morbidity (week wise) } \\
\text { within } 1 \text { st month }\end{array}$} & \multirow{2}{*}{$\begin{array}{l}\text { Percent } \\
\text { morbidity } \\
\text { (1st } \\
\text { month) }\end{array}$} & \multirow{2}{*}{$\begin{array}{l}\text { Percent } \\
\text { morbidity } \\
\text { (2nd } \\
\text { month) }\end{array}$} & \multirow{2}{*}{$\begin{array}{l}\text { Percent } \\
\text { morbidity } \\
\text { (3rd } \\
\text { month) }\end{array}$} & \multicolumn{3}{|c|}{ Percent mortality } \\
\hline & & & $\begin{array}{l}\text { 1st } \\
\text { week }\end{array}$ & $\begin{array}{l}\text { 2nd } \\
\text { week }\end{array}$ & $\begin{array}{l}\text { 3rd } \\
\text { week }\end{array}$ & $\begin{array}{l}\text { 4th } \\
\text { week }\end{array}$ & & & & $\begin{array}{l}\text { 1st } \\
\text { month }\end{array}$ & $\begin{array}{l}\text { 2nd } \\
\text { month }\end{array}$ & $\begin{array}{l}\text { 3rd } \\
\text { month }\end{array}$ \\
\hline \multirow[t]{2}{*}{ Jamunapari } & 10 & 13 & 7.69 & 15.38 & 15.38 & 23.08 & 38.46 & 46.15 & 50.00 & 00 & 7.69 & 8.33 \\
\hline & & & $(1 / 13)$ & $(2 / 13)$ & $(2 / 13)$ & $(3 / 16)$ & $(5 / 13)$ & $(6 / 13)$ & $(6 / 12)$ & & $(1 / 13)$ & $(1 / 12)$ \\
\hline \multirow[t]{2}{*}{ Barbari } & 10 & 16 & 12.5 & 31.25 & 37.5 & 18.75 & 62.50 & 18.75 & 25.00 & 00 & 00 & 6.25 \\
\hline & & & $(2 / 16)$ & $(5 / 16)$ & $(6 / 16)$ & $(3 / 16)$ & $(10 / 16)$ & $(3 / 16)$ & $(4 / 16)$ & & & $(1 / 16)$ \\
\hline \multirow[t]{2}{*}{ Jakharana } & 10 & 17 & 00 & 00 & 11.76 & 29.14 & 41.17 & 29.14 & 11.76 & 00 & 00 & 00 \\
\hline & & & & & $(2 / 17)$ & $(5 / 17)$ & $(7 / 17)$ & $(5 / 17)$ & $(2 / 17)$ & & & \\
\hline \multirow{2}{*}{$\begin{array}{l}\text { Non- } \\
\text { descript }\end{array}$} & 10 & 15 & 40.00 & 53.33 & 53.84 & 61.54 & 100.00 & 69.23 & 81.81 & 13.33 & 15.38 & 9.09 \\
\hline & & & $(6 / 15)$ & $(8 / 15)$ & $(7 / 13)$ & $(8 / 13)$ & $(15 / 15)$ & $(9 / 13)$ & $(9 / 11)$ & $(2 / 15)$ & $(2 / 13)$ & $(1 / 11)$ \\
\hline
\end{tabular}

It is now a well established fact that pregnant animals undergo some sort of immunosuppressive/ immunotolerant phase during gestation. The main reason behind this is the negative effect of metabolic stress on the immune function, health, and production during this period is well established (Sordillo and Aitken 2009). Metabolic stress starts several weeks before parturition, and therefore can potentially affect the fetus also (Sordillo and Raphael 2013). This may results into various acquired infections due to failure of passive transfer of immunity are considered a major cause of delayed and late postnatal diseases in neonates of farmed ruminants as at birth neonates are agammaglobulinemic and have immature innate and adaptive immune system and to resist infections in early postnatal life, they solely depend on maternal immunoglobulins present in colostrum (Radostits et al. 2007). Failure of passive transfer of immunity (FPTI) due to 
poor quality or inadequate ingestion of colostrum leads to increased morbidity and mortality in farm animals. Colostrum contains different immune components viz. immunoglobulins, antimicrobial peptides, cytokines, leukocytes and milk oligosaccharides etc. Mechanisms responsible for their synthesis factors regulating them are still poorly understood. This knowledge gap makes it difficult to select nutrientnutraceutical approach which although has proven immunomodulatory activity to alter the immune quality of colostrum. The trace mineral status of an animal is important during times of stress, especially for transition period because of stress due to fetal growth, colostrums production, as well as other hormonal, physiological, dietary and environmental changes they face (Leeson 2005). Colostrum is the main source of minerals for the neonates; hence mineral content of colostrum is largely affected by mineral supplementation to the dam during the transition period. Therefore, the use of supplemental trace minerals prior to parturition to increase the trace mineral content in fetal tissues and colostrum may help to enhance immunity in the neonates. Trace minerals such as copper, zinc and selenium deficiencies, impaired colostral transfer of immunoglobulin, which is the major reason of decreased resistance of calves, mainly resulting in perinatal mortality and also impair the acquired immunity in older calves (Enjalbert et al. 2006).

\section{Declarations:}

\section{Acknowledgement:}

Authors are thankful to the Hon'ble Vice Chancellor, DUVASU, Mathura and Director ICAR-CIRG for providing all the necessary help during the entire study. The authors are also thankful to Dr P K Shukla, Dean, COVSc\&AH, DUVASU, Mathura, for providing necessary facilities and support during the investigation.

Funding: The research was funded by ICAR, India

Conflicts of interest: the authors declaring no conflict of interest

Ethics approval: The guidelines for animal experimentation followed in this study were approved by Institutional Animal Ethics Committee and the ethical guidelines of DUVASU, Mathura were followed during all the experiments.

\section{Consent for publication:N/A}

\section{Availability of data and materials: N/A}

\section{Code availability: N/A}

Authors contribution: the study was part of PhD thesis work of $1^{\text {st }}$ author, $2^{\text {nd }}$ author designed the experiment, $3^{\text {rd }}$ and $4^{\text {th }}$ author help $1^{\text {st }}$ author in the experimental procedure

\section{References:}

1. Abd El-Fattah, A.M., Abd Rabo, F.H.R., El-Dieb, S.M., El-Kashef, H.A., 2012. Changes in composition of colostrum of Egyptian buffaloes and Holstein cows. BMC Veterinary Research, 8, 19.

2. Abdollahi, E., Kohram, H., Shahir, M.H., 2013. Plasma concentrations of essential trace microminerals and thyroid hormones during single or twin pregnancies in fat-tailed ewes. Small Ruminant Research, 113, 360-364.

3. Akhtar, M.S., Farooq, A.A., Mushtaq, M., 2009. Serum trace minerals variation during pre and post-partum period in Nili-Ravi buffaloes. The Journal of Animal and Plant Sciences, 19(4), 182-184.

4. Caroprese, M., Giannenas, I., Fthenakis, G., 2015. Interactions between nutritional approaches and defences against microbial diseases in small ruminants. Veterinary Microbiology, 181, 8-14.

5. Condron, L.M., Cameron, K.C., Di, H.J., Clough, T.J., Forbes, E.A., McLaren, R.G., Silva, R. G., 2000. A comparison of soil and environmental quality under organic and conventional farming systems in New Zealand. New Zealand Journal of Agricultural Research, 43(4), 443-466.

6. Condron, L.M., Cameron, K.C., Di, H.J., Clough, T.J., Forbes, E.A., McLaren, R.G., Silva, R. G., 2000. A comparison of soil and environmental quality under organic and conventional farming systems in New Zealand. New Zealand Journal of Agricultural Research, 43(4), 443-466.

7. Enjalbert, F., 2009. The relationship between trace elements status and health in calves. Revue Med. Vet., 160 (8-9), 429-435.

8. Gupta, V.P., Kumar, V., Roy, D., Kumar, M., 2015. Macro and micro-mineral profile of feeds, fodders and blood of livestock under farm condition in Mathura district of India. Indian Journal of Animal Research, 2851, 1-4. 
9. Hill, G.M., Shannon, M.C., 2019. Copper and zinc nutritional issues for agricultural animal production. Biol. Trace Element Research, 188, 148-159.

10. Jeong, S.G., Ham, J.S., Kim, D.H., Ahn, C.N., Chae, H.S., You, Y.M., Jang, A., Kwon, I.K., Lee, S.G., 2009. Physiochemical properties of colostrum by milking time of Gyeonggi Province. Korean Journal of Food Science Ann., 29, 445-456.

11. Kehoe, S.I., Jayarao, B.M., Heinrichs, A.J., 2007. A survey of bovine colostrum composition and colostrum management practices on Pennsylvania farms. Journal of Dairy Science, 90, 4108-4116.

12. Kincaid, R.L., 1999. Assessment of trace mineral status of ruminants: a review. Proc. Amer. Soc. Anim. Sci., 1-10.

13. Leeson, S., 2005. Trace mineral requirements of poultry-validity of the NRC recommendations. In: Taylor-Pickard JA, Tucker LA (eds) Redefining mineral nutrition. Nottingham University Press, Nottingham, 107-117.

14. Linn, J.G., Mary, L., Knight, R., Greg, L.G., 2011. Trace minerals in the dry period - boosting cow and calf health. WCDS Advances in Dairy Technology, 23, 271-286.

15. Meglia, G.E., Johannisson, A., Petersson, L., Persson Waller, K., 2001. Changes in some blood micronutrients, leukocytes and neutrophil expression of adhesion molecules in periparturient dairy cows. Acta veterinaria scandinaria, 42, 139-150.

16. Mora, A.M., van Wendel de Joode, B., Mergler, D., Cordoba, L., Cano, C., Quesada, R., Smith, D.R., Menezes-Filho, J.A., Lundh, T., Lindh, C.H., Bradman, A., Eskenazi, B., 2014. Blood and hair manganese concentrations in pregnant women from the infants environmental health study (ISA) in Costa Rica. Environ. Sci. Technol., 48(6), 3467-3476.

17. Quigley, J.D., Drewry, J.J., 1998. Nutrient and immunity transfer from cow to calf pre- and post calving. Journal of Dairy Science, 81, 2779-2790.

18. Radostits, O.M., Gay, C.C., Hinchcliff, K.W., Constable, P.D., 2007. Veterinary Medicine: A textbook of the diseases of cattle, sheep, goats, pigs and horses. 10th Edn. Saunders Elsevier, 127-128.

19. Sharma, M.C., Kumar, P., Joshi, C., Kaur, H., 2006. Status of serum minerals and biochemical parameters in cattle of organized farms and unorganized farms of western Uttar Pradesh. Asian Journal of Animal and Veterinary Advances, 1(1), 33-41.

20. Small, J.A., Charmley, E., Rodd, A.V., Fredeen, A.H., 1997. Serum mineral concentrations in relation to estrus and conception in beef heifers and cows fed conserved forage. Canadian Journal of Animal Science, 77, 55-62.

21. Sordillo, L.M., Aitken, S.L., 2009. Impact of oxidative stress on the health and immune function of dairy cattle. Veterinary Immunology and Immunopathology, 128,104-109.

22. Sordillo, L.M., Raphael, W., 2013. Significance of metabolic stress, lipid mobilization, and inflammation on transition cow disorders. Veterinary Clinic of North American Food and Animal Practice, 29, 267-278.

23. Xin, Z., Waterman, D.F., Hemken, R.W., Harmon, R.J., 1993. Copper status and requirement during the dry period and early lactation in multiparous Holstein cows. Journal of Dairy Science, 76, 2711- 2716. 